\title{
Cytotoxic Activity of Secondary Metabolites from the Bark of Dipterocarpus Confertus Sloot
}

\author{
Muhtadi $^{1}$, Peni Indrayudha ${ }^{1}$, Agustono Wibowo ${ }^{2}$, and Khong Heng Yen ${ }^{3}$ \\ ${ }^{1)}$ Faculty of Pharmacy, Universitas Muhammadiyah Surakarta, Jalan A. Yani Tromol Pos I Pabelan \\ Kartasura, Surakarta 57102, Indonesia \\ *muhtadi@ums.ac.id \\ ${ }^{2)}$ Faculty of Applied Sciences, Universiti Teknologi MARA (UiTM) 40450 Shah Alam, Selangor, Malaysia \\ nico4orgchem@yahoo.com \\ ${ }^{3)}$ School of Chemistry and Environtmental Studies, Faculty of Applied Sciences, Universiti Teknologi MARA \\ (UiTM) Sarawak, 94300 Kota Samarahan, Sarawak, Malaysia. \\ khonghy@sarawak.uitm.edu.my
}

\section{ABSTRACT}

Four compounds, namely $\beta$-sitosterol (1), betulinic acid (2), cinnamic acid (3), and $\alpha$-viniferin (4) have been successfully isolated from the bark methanol extract of Dipterocarpus confertus Sloot. The structures of the isolated compounds have been established on the basis spectroscopic data evidence, and comparison with the published data. In the cytotoxicity study, cinnamic acid (3) and betulinic acid (2) have been found to be very strong active against murine leukemia P388 and vero cells lines with the $\mathrm{IC}_{50}$ values of 2.25 and $5.10 \mu \mathrm{g} / \mathrm{mL}$, respectively, while the other compounds were not active.

\section{Keywords}

Dipterocarpaceae; Dipterocarpus confertus; Phenolic; Oligostilbenoid; Terpenoid and Cytotoxic

\section{Academic Discipline And Sub-Disciplines}

Pharmacy

\section{SUBJECT CLASSIFICATION}

Natural drug discovery

\section{TYPE (METHOD/APPROACH)}

\section{Experimental}

\section{Council for Innovative Research}

Peer Review Research Publishing System

Journal: Journal of Advances in Chemistry

Vol. 9, No. 1

editorjaconline@gmail.com

www.cirworld.org/journals 


\section{INTRODUCTION}

Dipterocarpus confertus, which known with local name "Keruing Pungguh" in Indonesia is a species of genus Dipterocarpus (Dipterocarpaceae). Dipterocarpus is the third largest genus in the family of Dipterocarpaceae with 75 species [1,2]. As other genus in Dipterocarpaceae, Dipterocarpus has been known as a rich source of oligostilbenoid type of compounds, as well as other type of phenolic compounds $[3,4,5,6,7]$. The secondary metabolites of Dipterocarpaceae have withdrawn much attention of many scientists due to the structural complexity, and their biological activities such as antifungal [8,9], anti-HIV [10], cytotoxic [10, 11, 3, 4], anti-inflammatory [12, 13] and antibacterial [14, 15, 7]. Our previous study reported the isolation of phenolic compounds from Dipterocarpus as well as their cytotoxic activity [4, 16]. In continuation of our interest in the phytochemical study of phenolic compounds in the new species Dipterocarpus plant, we report here the cytotoxicity of four compounds isolated from the bark of Dipterocarpus confertus.

\section{EXPERIMENTAL}

\section{General experimental procedure}

The following instruments were used: UV and IR spectrum were measured with a Varian Conc. 100 instruments and a Perkin Elmer Spectrum One FTIR spectrometer, respectively. The ${ }^{1} \mathrm{H}$ and ${ }^{13} \mathrm{C}$ NMR spectrum were recorded with JEOL Model ECP400 Spectrophotometer $\left[400 \mathrm{MHz}\left({ }^{1} \mathrm{H}\right)\right.$ and $\left.100 \mathrm{MHz}\left({ }^{13} \mathrm{C}\right)\right]$. The following adsorbents were used for purification: vacuum liquid chromatography (Si-gel 60, Merck catalog number: 1.07747) and flash column chromatography (Si-gel $60 \mathrm{GF}_{254}$, Merck catalog number: 1.07749), and TLC analysis (Merck, Kieselgel $60 \mathrm{~F}_{254} 0.25 \mathrm{~mm}$ ). Solvents used in this research are analytical grade and technical grade that were distilled before used.

\section{Plant material}

The bark of $D$. confertus was collected from Bukit Bengkirai, East Kalimantan, Indonesia, and a voucher specimen has been deposited at the Herbarium Bogoriensis, Research Center for Biology, Indonesian Institute of Science, Bogor, Indonesia (collection number SR-027).

\section{Extraction and isolation}

The dried powder of the bark of $D$. confertus Sloot $(4.3 \mathrm{~kg})$ was macerated with methanol $(3 \times 10 \mathrm{~L})$, and evaporated under reduced pressure to give a dark brown residue $(467 \mathrm{~g})$. The dried methanol extract was dissolved in a small volume of $\mathrm{MeOH}( \pm 300 \mathrm{~mL})$, and added with diethyl ether to a volume $\pm 2 \mathrm{~L}$ to give $\mathrm{MeOH}$-diethyl ether soluble fraction (284 g) after decantation and evaporation, and an insoluble fraction (183 g). A Part of the soluble fraction $(60 \mathrm{~g})$ was subjected to vacuum liquid chromatography (VLC), and eluted with mixtures of $n$-hexane/EtOAc $40 \%$ to $100 \%$, and EtOAc/MeOH $10 \%$, $20 \%$ and $100 \%$ to give nine major fractions $\left(F_{1}-F_{9}\right)$. Furthermore, refractionation of fraction $F_{3}(500 \mathrm{mg})$ by using flash column chromatography (eluent, $n$-Hexane:EtOAc 8:2), and then recrystallization of fraction $F_{32}$ and $F_{36}$ from this steps yielded cinnamic acid $(\mathbf{3})(113 \mathrm{mg})$ and $\beta$-sitosterol $(\mathbf{1})(105 \mathrm{~m} \mathrm{~g})$, respectively. Fractions $F_{4}$ and $F_{5}$ performed the similar crystal form. Recrystallization and washing of this fraction with acetone and methanol yielded betulinic acid (2) (190 mg). Fraction $\mathrm{F}_{8}(670 \mathrm{mg})$ was purified using flash column chromatography with the combination of $n$-Hexane:EtOAc 8.5:1.5 as solvent system gave $\alpha$-viniferin (4) (210 mg).

$\beta$-sitosterol (1): white amorphous powder; ${ }^{1} \mathrm{H}$ NMR $\left(400 \mathrm{MHz}, \mathrm{CDCl}_{3}\right) ; \delta_{\mathrm{H}} 5.39(1 \mathrm{H}, m, \mathrm{H}-6), 3.51(1 \mathrm{H}, m, \mathrm{H}-3), 1.05(3 \mathrm{H}$, $s$, Me-19), $0.97(3 \mathrm{H}, d, J=6.5 \mathrm{~Hz}, \mathrm{Me}-21), 0.90(3 \mathrm{H}, t, J=7.4 \mathrm{~Hz}, \mathrm{Me}-29), 0.87(3 \mathrm{H}, d, J=6.7 \mathrm{~Hz}, \mathrm{Me}-26), 0.85(3 \mathrm{H}, d, J=6.7$ $\mathrm{Hz}, \mathrm{Me}-27)$ and $0.72(3 \mathrm{H}, \mathrm{s}, \mathrm{Me}-18)$.

Betulinic acid (2): white powder, ${ }^{1} \mathrm{H}$ NMR $\left(400 \mathrm{MHz}, \mathrm{CDCl}_{3}\right): \delta_{\mathrm{H}} 3.10(1 \mathrm{H}, d d, J=5.48,11.36 \mathrm{~Hz}, \mathrm{H}-3), 2.99(1 \mathrm{H}, t d$, $J=4.76,10.64 \mathrm{~Hz}, \mathrm{H}-19), 0.91(3 \mathrm{H}, s, \mathrm{H}-23), 0.71(3 \mathrm{H}, s, \mathrm{H}-24), 0.82(3 \mathrm{H}, s, \mathrm{H}-25), 0.93(3 \mathrm{H}, s, \mathrm{H}-26), 0.97(3 \mathrm{H}, s, \mathrm{H}-27)$, $4.67(1 \mathrm{H}, d, J=2.2 \mathrm{~Hz}, \mathrm{H}-29 \mathrm{a}), 4.55(1 \mathrm{H}, d, J=2.2 \mathrm{~Hz}, \mathrm{H}-29 \mathrm{~b})$ and $1.66(3 \mathrm{H}, s, \mathrm{H}-30) .{ }^{13} \mathrm{C} \mathrm{NMR}\left(100 \mathrm{MHz}^{-} \mathrm{CDCl}_{3}\right): \delta_{\mathrm{C}}$ 40.25 (C-1), 28.21 (C-2), 79.84 (C-3), 40.14 (C-4), 57.05 (C-5), 19.54 (C-6), 35.77 (C-7), 42.10 (C-8), 52.19 (C-9), 38.38 (C-10), 22.27 (C-11), 27.08 (C-12), 39.82 (C-13), 43.76 (C-14), 31.04 (C-15), 33.59 (C-16), 57.74 (C-17), 50.63 (C-18), 48.55 (C-19), 152.24 (C-20), 31.91 (C-21), 38.51 (C-22), 28.79 (C-23), 16.30 (C-24), 16.91 (C-25), 16.84 (C-26), 15.30 (C27), 180.40 (C-28), 110.32 (C-29) and 19.63 (C-30).

Cinnamic acid (3): white powder, ${ }^{1} \mathrm{H}$ NMR $\left(400 \mathrm{MHz}, \mathrm{CDCl}_{3}\right) ; \delta_{\mathrm{H}} 11.01(1 \mathrm{H}, b r s, \mathrm{OH}), 7.81(1 \mathrm{H}, d, \mathrm{~J}=16 \mathrm{~Hz}, \mathrm{H}-7), 7.57$ $(2 \mathrm{H}, m, \mathrm{H}-2 / 6), 7.42(3 \mathrm{H}, \mathrm{m}, \mathrm{H}-3 / 4 / 5), 6.47(1 \mathrm{H}, \mathrm{d}, \mathrm{J}=16 \mathrm{~Hz}, \mathrm{H}-8) .{ }^{13} \mathrm{C}$ NMR $\left(100 \mathrm{MHz}, \mathrm{CDCl}_{3}\right) ; \delta_{\mathrm{C}} 172.06(\mathrm{C}=\mathrm{O}), 147.11$ (C-7), 133.99 (C-1), 130.77 (C-4), 128.96 (C-3, C-5), 128.37 (C-2, C-6) and 117.17 (C-8).

(-)- $\alpha$-viniferin (4): yellow powder, ${ }^{1} \mathrm{H}$ NMR $\left(400 \mathrm{MHz}\right.$, acetone- $\left.d_{6}\right) ; \delta_{\mathrm{H}} 7.01(2 \mathrm{H}, \mathrm{d}, \mathrm{J}=8.8 \mathrm{~Hz}, \mathrm{H}-2 \mathrm{a} / 6 \mathrm{a}), 6.70(2 \mathrm{H}, d, \mathrm{~J}=8.8$ $\mathrm{Hz}, \mathrm{H}-3 \mathrm{a} / 5 \mathrm{a},), 6.07(1 \mathrm{H}$, brs, H-7a), $3.95(1 \mathrm{H}$, brs, H-8a), $6.22(1 \mathrm{H}, d, J=1.8 \mathrm{~Hz}, \mathrm{H}-12 \mathrm{a}), 6.71(1 \mathrm{H}, d, J=1.8 \mathrm{~Hz}, \mathrm{H}-14 \mathrm{a})$, $7.02(2 \mathrm{H}, d, J=8.8 \mathrm{~Hz}, \mathrm{H}-2 \mathrm{~b} / 6 \mathrm{~b}), 6.78(2 \mathrm{H}, d, J=8.8 \mathrm{~Hz}, \mathrm{H}-3 \mathrm{~b} / 5 \mathrm{~b}), 4.90(1 \mathrm{H}, d, J=6.2 \mathrm{~Hz}, \mathrm{H}-7 \mathrm{~b}), 4.60(1 \mathrm{H}, d, J=6.2 \mathrm{~Hz}$, $\mathrm{H}-8 \mathrm{~b}), 6.24(1 \mathrm{H}, d, J=2.0 \mathrm{~Hz}, \mathrm{H}-12 \mathrm{~b}), 5.98(1 \mathrm{H}, d, J=2.0 \mathrm{~Hz}, \mathrm{H}-14 \mathrm{~b}), 7.22(2 \mathrm{H}, d, J=8.8 \mathrm{~Hz}, \mathrm{H}-2 \mathrm{c} / 6 \mathrm{c}), 6.76(2 \mathrm{H}, d, J=8.8$ $\mathrm{Hz}, \mathrm{H}-3 \mathrm{c} / 5 \mathrm{c}), 5.92(1 \mathrm{H}, d, J=10.0 \mathrm{~Hz}, \mathrm{H}-7 \mathrm{c}), 4.68(1 \mathrm{H}, d, J=10.0 \mathrm{~Hz}, \mathrm{H}-8 \mathrm{c}), 6.20(1 \mathrm{H}, d, J=2.0 \mathrm{~Hz}, \mathrm{H}-12 \mathrm{c})$ and $6.59(1 \mathrm{H}$, $d, J=2.0 \mathrm{~Hz}, \mathrm{H}-14 \mathrm{c}) .{ }^{13} \mathrm{C}-\mathrm{NMR}\left(100 \mathrm{MHz}\right.$, acetone- $\left.d_{6}\right) ; \delta_{\mathrm{c}} 132.0(\mathrm{C}-1 \mathrm{a}), 128.2(\mathrm{C}-2 \mathrm{a} / 6 \mathrm{a}), 115.7(\mathrm{C}-3 \mathrm{a} / 5 \mathrm{a}), 158.2(\mathrm{C}-4 \mathrm{a})$, 86.4 (C-7a), 46.4 (C-8a), 141.2 (C-9a), 120.9 (C-10a), 160.6 (C-11a), 98.0 (C-12a), 159.3 (C-13a), 106.2 (C-14a), 132.5 (C-1b), 128.7 (C-2b/6b), 116.1 (C-3b/5b), 158.4 (C-4b), 95.6 (C-7b), 55.7 (C-8b), 141.2 (C-9b), 118.8 (C-10b), 161.6 (C11b), 98.0 (C-12b), 159.3 (C-13b), 108.6 (C-14b), 132.0 (C-1c), 128.1 (C-2c/6c), 116.1 (C-3c/5c), 157.9 (C-4c), 90.0 (C7c), 52.8 (C-8c), 138.7 (C-9c), 119.7 (C-10c), 161.7 (C-11c), 96.9 (C-12c), 160.7 (C-13c) and 105.8 (C-14c). 


\section{Cytotoxic Activity}

The cytotoxicity was determined by MTT 3-(4,5-dimethylthiazol-2-yl)-2,5-diphenyltetrazolium bromide assay against P388 and Vero cell lines. The assay was performed as described by Mosmann (1983)[17], but with slight modifications. MTT was first prepared are a stock solution of $5 \mathrm{mg} / \mathrm{ml}$ in phosphate buffer (PBS, $\mathrm{pH} \mathrm{7.2)} \mathrm{and} \mathrm{filtered.} \mathrm{Samples} \mathrm{of} \mathrm{different}$ concentration of the extracts were prepared in triplicates. At the end of the treatment period (72h), $20 \square$ I of MTT solution was added to each sample and incubated for 3 hours. After 72 h, supernatants were discarded and $50 \mu$ of MTT stock solution $(5 \mathrm{mg} / \mathrm{ml})$ were added to each well and the plates were further incubated for four hours. After that, supernatant was removed, and the formazan crystals were dissolved with $100 \mu \mathrm{l}$ DMSO. The amount of MTT-formazan was directly proportional to the number of living cells, and was determined by measuring the optical density (OD) at $570 \mathrm{~nm}$ using microplate reader ( $\square$ Quant Universal Microplate Spectrophotometer, BIOTEK Instrument, Inc.). The IC $\mathrm{C}_{50}$ values represented the concentration that reduced the mean absorbance at $570 \mathrm{~nm}$ to $50 \%$ of those in the untreated control wells [18].

\section{RESULTS AND DISCUSSION}

The methanol extract of the stem bark of $D$. confertus was separated by combination of vacuum liquid and flash column chromatographies have resulted the isolation and characterization of compounds 1-4. The structure of these compounds were identified on the basis of spectroscopic data evidence as steroid; $\beta$-sitosterol (1)[19], pentacyclic triterpene; betulinic acid (2)[20], cinnamic acid (3) [21], and oligomeric resveratrol; $\alpha$-viniferin (4)[12] (Fig. 1). All compounds were isolated for the first time from this plant.

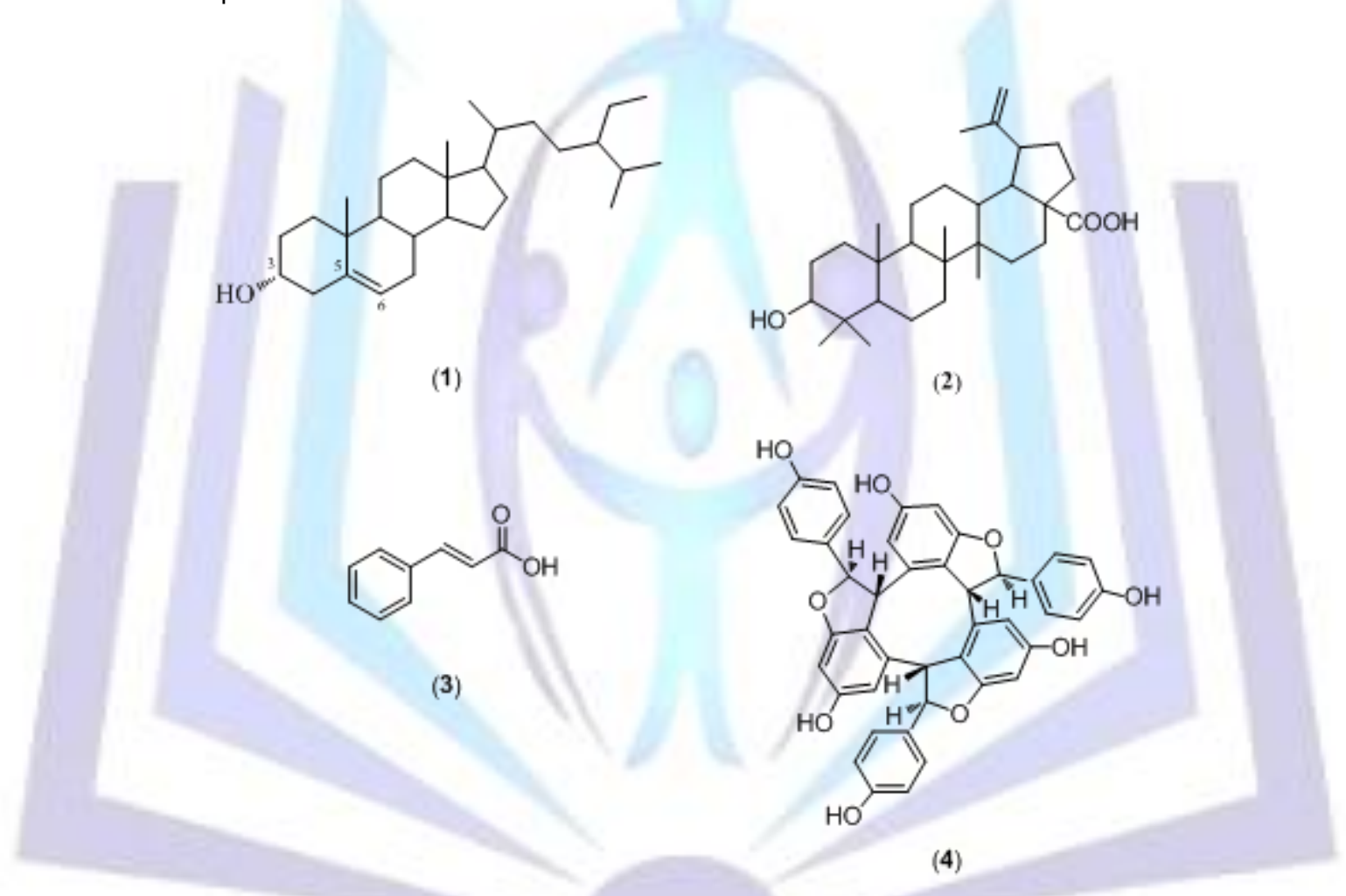

Fig. 1. The structure of isolated compounds

The cytotoxicity of all isolated compounds from the bark of $D$. confertus was tested against P-388 mice leukemia and Vero normal kidney monkey cell lines. From the assay, cinnamic acid (3) and betulinic acid (2) demonstrated potent activity against P-388 cell lines with $\mathrm{IC}_{50}$ value of 2.25 and $5.10 \mu \mathrm{g} / \mathrm{ml}$, respectively. However, they showed different response against normal vero cell, in which betulinic acid (2) was toxic to the cell (IC $\left.\mathrm{C}_{50} 6.19 \mu \mathrm{g} / \mathrm{ml}\right)$, while cinnamic acid (3) was not toxic $\left(\mathrm{IC}_{50} 69823.24 \mu \mathrm{g} / \mathrm{ml}\right)$. On the other hand, other compounds were only in the range of the lowest and not active against both cell lines (Table 1). This fact indicated that only $\mathbf{3}$ displays high potency as anticancer agent, as it is only toxic to the cancer cell and not to the host cell. 
Table 1. Inhibitory concentration of $50 \%$ by P-388 and Vero cell lines

\begin{tabular}{|l|c|c|}
\hline \multirow{2}{*}{ Compound } & \multicolumn{2}{|c|}{ Cytotoxic activity $\left(\mathbf{I C}_{50} \mathbf{~} \mathbf{g} / \mathbf{m l}\right)$} \\
\cline { 2 - 3 } & $\mathbf{P - 3 8 8}$ & Vero \\
\hline$\beta$-Sitosterol (1) & nd & nd \\
\hline Betulinic acid (2) & 5.10 & 69823.24 \\
\hline Cinnamic acid (3) & 2.25 & 6.19 \\
\hline$\alpha$-Viniferin (4) & 71.00 & 438.26 \\
\hline
\end{tabular}

In this study, compound $\mathbf{3}$ is more active compared to $\mathbf{2}$ even though they contain similar acid group. This may be due to the existence of conjugate system in the skeleton of $\mathbf{3}$, which activated its aromatic ring. This suggestion was supported by Otero et al. (2013) [22], which found that the cytotoxicity of chalcone and coumarin increased with the presence of conjugated double bond in the side chain. The similar case was displayed by compound $\mathbf{2}$, which showed stronger activity compared to $\mathbf{1}$. Several literatures reported that compound $\mathbf{2}$ is a pentacyclic triterpenoid that commonly studied, and the studies have been focused on the modifications of carbons C-3 and C-28. Ding et al. (2013) [23] reported that electrondonating groups at the C-28 and C-3 of 2 would improve the activity.

\section{ACKNOWLEDGEMENTS}

We gratefully acknowledge financial support provided by the Hibah Bersaing from Directorate General of Higher Education, Ministry of Education and Cultural Republic Indonesia; Dr. Edi Karyadi (University Tanjungpura of Pontianak) for his kind assistance and collection of the sample, and staff of Herbarium Bogoriensis Bogor for determination of plant samples.

\section{REFERENCES}

[1] Ashton, P.S., Arnold, A., 1983. Flora Malesiana: Spermatophyta I, in: Steenis, C.G.G.J. (Ed.), Flora Malesiana. Noordhoff-Kolff, pp. 391-436.

[2] Newman, M.F., Burgess, P.F., Whitmore, T.C., 1998. Manuals of dipterocarps for foresters: Sumatra medium and heavy hardwoods: Dipterocarpus, Dryobalanops, Hopea, Shorea (balau). Center for International Forestry Research, Bogor, Indonesia.

[3] Syah, Y.M., Aminah, N.S., Hakim, E.H., Aimi, N., Kitajima, M., Takayama, H., Achmad, S.A., 2003. Two oligostilbenes, cis- and trans-diptoindonesin B, from Dryobalanops oblongifolia. Phytochemistry 63, 913-917.

[4] Muhtadi, Hakim, E.H., Juliawaty, L.D., Syah, Y.M., Achmad, S.A., Latip, J., Ghisalberti, E.L., 2006. Cytotoxic resveratrol oligomers from the tree bark of Dipterocarpus hasseltii. Fitoterapia 77, 550-555.

[5] Wibowo, A., Ahmat, N., Hamzah, A.S., Sufian, A.S., Ismail, N.H., Ahmad, R., Jaafar, F.M., Takayama, H., 2011. Malaysianol A, a new trimer resveratrol oligomer from the stem bark of Dryobalanops aromatica. Fitoterapia 82 , 676-681.

[6] Wibowo, A., Ahmat, N., Hamzah, A.S., Ismail, N.H., Ahmad, R., Jaafar, F.M., 2012a. Resveratrol oligomers from the stem bark of Dryobalanops aromatica. Biochem. Syst. Ecol. 40, 62-64.

[7] Wibowo, A., Ahmat, N., Hamzah, A.S., Low, A.L.M., Mohamad, S.A.S., Khong, H.Y., Sufian, A.S., Manshoor, N., Takayama, H., 2012b. Malaysianol B, an oligostilbenoid derivative from Dryobalanops lanceolata. Fitoterapia 83, 1569-1575.

[8] Pryce, R.J., and Langcake, P., 1977. a-Viniferin: An antifungal resveratrol trimer from grapevines. Phytochemistry 16, 1452-1454.

[9] Bokel, M., Diyasena, M.N.C., Gunatilaka, A.A.L., Kraus, W., Sotheeswaran, S., 1988. Canaliculatol, an antifungal resveratrol trimer from Stemonoporous canaliculatus. Phytochemistry 27, 377-380.

[10] Dai, J., Hallock, Y.F., Cardellina, J.H., Boyd, M.R., 1998. HIV-inhibitory and cytotoxic oligostilbenes from the leaves of Hopea malibatol. J. Nat. Prod. 61, 351-353.

[11] Ito, T., Akao, Y., Yi, H., Ohguchi, K., Matsumoto, K., Tanaka, T., linuma, M., Nozawa, Y., 2003. Antitumor effect of resveratrol oligomers against human cancer cell lines and the molecular mechanism of apoptosis induced by vaticanol C. Carcinogenesis 24, 1489-1497.

[12] Kitanaka, S., Ikezawa, T., Yasukawa, K., Yamanouchi, S., Takido, M., Kil Sung, H., Hyuk Kim, I., 1990. (+)-aviniferin, an anti-inflammatory compound from Caragana chamlagu root. Chem. Pharm. Bull. 38, 432-435. 
[13] Huang, K.S., Lin, M., Cheng, G.F., 2001. Anti-inflammatory tetramers of resveratrol from the roots of Vitis amurensis and the conformations of the seven-membered ring in some oligostilbenes. Phytochemistry 58, 357362.

[14] Gunawardena, Y.A.G.P., Sotheeswaran, S., Sultanbawa, M.U.S., Surendrakumar, S., Bladon, P., 1986. Another antibacterial polyphenol, copalliferol B, from Vateria copallifera (Dipterocarpaceae). Phytochemistry 25, 14981500.

[15] Zgoda-Pols, J.R., Freyer, A.J., Killmer, L.B., Porter, J.R., 1996. Antimicrobial Resveratrol Tetramers from the Stem Bark of Vatica oblongifolia ssp. oblongifolia. J. Nat. Prod. 65, 1554-1559.

[16] Muhtadi, 2007. Phytochemical Investigation of Some Indonesian Dipterocarpaceae Species of the Genus Dipterocarpus, Doctoral Program, Postgraduate School. ITB, Bandung, p. 142.

[17] Mosmann, T., 1983. Rapid colorimetric assay for cellular growth and survival: Application to proliferation and cytotoxicity assays. J. Immunol. Methods 65, 55-63.

[18] Alley, M.C., Scudiero, D.A., Monks, A., Hursey, M.L., Czerwinski, M.J., Fine, D.L., Abbott, B.J., Mayo, J.G., Shoemaker, R.H., Boyd, M.R., 1988. Feasibility of Drug Screening with Panels of Human Tumor Cells Lines Using a Microculture Tetrazolilum Assay, Cancer Res., 48, 589-601.

[19] Lee, I.K., Kim, M.A., Lee, S.Y., Hong, J.K., Lee, J.H., Lee, K.R., 2008. Phytochemical constituents of Schizonepeta tenuifolia Briquet. Nat. Prod. Sci. 14, 100-106.

[20] Barba, B., Díaz, J.G., Herz, W., 1992. Anthraquinones and other constituents of two Senna species. Phytochemistry 31, 4374-4375.

[21] Bourne, E.J., MacLeod, N.J., Pridham, J.B., 1963. The identification of naturally occurring cinnamic acid derivatives. Phytochemistry 2, 225-230.

[22] Otero, E., Robledo, S.M., Díaz, S., Carda, M., Muñoz, D., Paños, J., Vélez, I.D., Cardona, W., 2013. Synthesis and leishmanicidal activity of cinnamic acid esters: structure-activity relationship. Med. Chem. Res., 1-9.

[23] Ding, W., Sun, M., Luo, S., Xu, T., Cao, Y., Yan, X., Wang, Y., 2013. A 3D QSAR study of betulinic acid derivatives as anti-tumor agents using topomer CoMFA: Model building studies and experimental verification. Molecules 18, 10228-10241. 